\title{
Uluslararası Sağlık Turizminde Hastanın Özel Hayatının Gizliliği ve Mahremiyetinin Korunması Hakk1
}

\author{
DOI: 10.26466/opus.480676 \\ *
}

$\underline{\text { Ayșegül Karaca Dedeoğlu }}{ }^{*}$

* Dr. Öğr. Üyesi, Karabük Üniveristesi Adalet Meslek Yüksek Okulu Karabük/ Türkiye

E-Mail: aysegulkaraca@karabuk.edu.tr

ORCID: $\underline{0000-0001-5777-948 X}$

\section{$\ddot{O} z$}

Uluslararası sağllk turizmi ülkemizde de gitgide büyümekte ve büyük bir endüstri olma yolunda ilerlemektedir. Birden fazla paydaşı olan bu endüstride; gerek paydaşların yapısal durumlarından kaynaklanan nedenler gerekse bu alana ilişkin yapılan hukuki düzenlemelerde sağllk turistlerinin en temel haklarından biri olan özel hayatın gizliliği ve mahremiyet hakkına ilişkin sorunlu alanlar kendini göstermeye başlamıştır. Sağllk kuruluşlarına başvuran sağlık turistlerinin tüm kişisel bilgilerinin merkezi sağlık sistemine aktarılmasını düzenleyen Sağlık Turizmi Yönetmeliği, sağlık kuruluşları dışında "aracı kurum" olarak nitelendirilen seyahat acentalarının sağllk turistlerine ait hassas sağllk verilerinin muhafaza sorunu ve genel olarak sağllk kurumu ve hekimlerin en fazla ihmal ettiği özel hayatın gizliliği ve mahremiyet hakkı ihlali bu konuyu çalışmamızın temel amacı olmuştur. Araştırmada nitel araştırma yöntemlerinden olan doküman analiz yöntemi kullanılmıştır. Özel hayatın gizliliği ve hasta mahremiyetine ilişkin uluslararası bildirgeler, sözleşmeler ve ulusal mevzuat ve yargı kararları ile idari düzenlemeler incelenip analiz edilmiştir.

Anahtar Kelimeler: Sağlık hukuku, Sağlık turizmi, Özel hayatın gizliliği, Mahremiyet, Kişisel sağlık verileri 


\title{
The Right to Protect Privacy and Private of Life of the Patient in International Health Tourism
}

\begin{abstract}
International health tourism is growing gradually in our country and is on the way of becoming a big industry. In this industry which has more than one stakeholder, problematic areas about one of the most basic rights of tourist; the right of private of life and privacy began to emerge from both the reasons arising from the structural conditions of the stakeholders and the legal regulations related to this field.The purpose of this study is to investigate the regulation of health tourism which regulates the transfer of all personal information of the health tourists to the central health system, the problem of preservation of sensitive health information belongs to health tourists by travel agencies, which are considered as intermediary institutions apart from health institutions, and the most neglected thing by physicians; the infringement of the right of private of life and privacy. The qualitative research method is used to collect the data. International declarations, conventions and national legislation, judicial decisions and administrative regulations regarding the private of life and patient's privacy have been examined and analyzed.
\end{abstract}

Key- Health law, Health tourism, The right to private life, Privacy, Personal health data. words: 


\section{Giriş}

Uluslararası sağlık turizmi, ${ }^{1}$ bireylerin ihtiyacı olan sağlık hizmetini ikamet ettiği ülke dışındaki farklı bir ülkeden almasıdır. Bu turizm özgün bir turizm çeşidi olup "tıbbi bakım veya tedavi amacıyla bir ülkeden diğerine seyahat etme uygulaması" olarak tanımlanmaktadır Conley, 2013, s.192).

Sağllk turizminin temel nedeni hastanın daha kaliteli, ekonomik ve erişebilir sağlık hizmetleri arayışı ve özel hayatın gizliliğine ve mahremiyetine verdiği önem ve ayrıca sağlı̆̆ın hukuksal kısıtlılıkları gibi faktörlerdir.

Sağlık hizmetlerinin küreselleşmesinin bir sonucu olarak doktriner ve normatif çok sayıda sorun da ortaya çıkmıştır (Cohen, 2010, s.1475). Bu sorunlardan biri de sınır dışı sağlık hizmetleri alan hastaların özel hayatının gizliliği ve mahremiyet hakkının korunması sorunudur. Sağlık turistinin bu sorunu sağlık hizmeti almak üzere doğrudan sağlık kuruluşuna veya aracı kurum veya kişiyle ilk temasından itibaren başlamakta; sağlık hizmetinin sunulma sürecinde ve sonrasında da devam etmektedir. Sağlık turistinin, sağlık hizmetlerinden faydalanmak amaciyla ilişki kurduğu her kişi ve kurumdan ve gittiği ülkenin devletinden özel hayatına dair bilgilerinin muhafazasını ve bu bilgilere başkalarınca ulaşılmamasına yönelik beklenti ve talebi bulunmaktadır. Çünkü sağlık hizmetlerinde özel hayatın gizliliği ve mahremiyet hakkl; tıp etiği, insan hakları, ulusal ve ulusal üstü hukuk açısından temel bir hak olarak tanınmakta ve bu hakkın ihlali birden fazla insan hakkı ihlaline sebep olmaktadır.

En temel hasta haklarından biri olan "özel hayatın gizliliği ve mahremiyetin korunması hakkı" 2 sağlık turizminde çeşitli paydaşlar tarafından ihlal edilme olasılığına sahiptir. Bu olası ihlallerin olgusal, yönetimsel ve hukuki olup olmadığı bu çalışmada el alınıp incelenmiştir.

Çalışmanın ilk bölümünde, sağlık turizmi ve ortaya çıkış nedenleri ile sağlık turizminde önemli paydaşlardan biri olan "aracı kurumlar"

\footnotetext{
${ }^{1}$ Kısaca sağlık turizmi olarak bahsedilecektir.

2 Özel hayat kavramı, mahremiyeti de kapsayan bir üst kavram olarak kabul edilse de sınırları ve kapsamIarı farkıdır. Çalışmada bu iki kavramı birlikte kullanmamızın nedeni hasta haklarına ilişkin "mahremiyet hakkı" kabul görmüş bir hak olmasına rağmen "özel hayat" kavramından daha az kapsayıcı bir özelliğe sahip olması ve uluslararası sözleşmelerde her iki kavramın da ayrı bir şekilde kullanılmasıdır.
} 
incelenmiştir. İkinci bölümde, mahremiyet, özel hayatın gizliliği, kişisel veriler, özel nitelikli kişisel veriler gibi temel kavramlar uluslararası bildirge, sözleşme ve ulusal mevzuat ışığında ele alınmış ve sağlık turistinin özel hayatının gizliliği ve mahremiyet hakkı bu bağlamda değerlendirilmiştir.

Çalışmanın yöntemi olarak nitel araştırma yöntemlerinden biri olan doküman analizi kullanılmıştır. Özel hayatın gizliliği ve hasta mahremiyetine ilişkin uluslararası bildirge, sözleşme ve Türk ulusal mevzuat, yargı kararları ile idari düzenlemeler incelenmiştir. ${ }^{3}$

\section{Sağlık Turizmi}

Roma İmparatorluğu döneminden günümüze değin, ikamet ettiği yerde çeşitli nedenlerden dolayı ihtiyaç duyduğu sağlık hizmetlerine erişemeyen bireyler, bu hizmetlere erişmek için sınır ötesi seyahat etmektedirler (Bennie, 2014, s.584).

Sağlık turizmi içinde sıkça kullanılan "turistin sağlığı" kavramı, sağlık amacı haricinde yapılan bir başka turizm faaliyeti süresince kişilerin gittikleri yerde sağlık hizmetlerinden faydalanmaları durumudur. Turistik gezi sırasında acil bir şekilde ve plansız olarak sağlık hizmeti alma zorunluluğu doğanların (trafik ve ev kazaları, zehirlenme, böcek sokmaları, boğulma, akut hastalıklar vb. sebeplerle sağlık hizmeti alma durumunda kalanlar) yanısıra, tatille birlikte tedavi amaçlı sağlık hizmet alanlar bulunmaktadır (Gönenç, 2016, s.1176).

2017 yılında yürürlüğe giren "Uluslararası Sağlık Turizmi ve Turistin Sağlığ1 Hakkında Yönetmelik" ${ }^{4}$ (Sağlık Turizmi Yönetmeliği) m. 4/d'de sağlık turizmini "Sağlık amaçh yurtdışından ülkemize geçici bir süreliğine gelen, Türkiye Cumhuriyeti vatandaşı olmayan veya Türkiye Cumhuriyeti vatandaşı olmakla birlikte yurtdışında ikamet eden gerçek kişilerin aldıkları her türlü sağlık hizmeti ile bunlarla ilgili destek hizmetleri." olarak tanımlamıştır.

Dünya Turizm Örgütünün yapmış olduğu bir araştırmaya göre tüm Dünya'da turizm hareketlerinin yüzde yirmiyedisini sağlık turizmi oluşturmaktadır (Birdir ve Buzcu, 2014). Sağlık Bakanlığı'nın raporuna

\footnotetext{
${ }^{3}$ Milletlerarası Özel Hukuktan kaynaklanan ihtilaflar bu çalışmanın kapsamı dışında bırakılmıştır.

${ }^{4} 13$ Temmuz 2017 tarih ve 30123 sayılı Resmi Gazete
} 
göre, günümüzde sağlık turizmi kapsamında bulunduğu ülke dişından sağlık hizmeti almak için yılda otuz milyon insan seyahat etmektedir. Tüm Dünyadaki sağlık turizmi harcamalarının ise yaklaşık beşyüz milyar dolar olduğu tahmin edilmektedir (Sağlık Turizmi Hakkında, 2018) Sağlık turizminin yapıldığı ülke açısından sağlık turizminin yapılmasının en temel faktörü, ekonomik nedenlerdir. Sağlık turizminin gelişmesi için özellikle gelişmekte olan ülkelerin ilgili bakanlıkları, ekonomik teşvikler sunmakta, devlet politikaları üretmektedir. ${ }^{5}$ Isşte bu noktada Türkiye, bulunduğu coğrafi konumun bir avantajını kullanarak, ulaşımın daha ekonomik ve rahat olması; sağlık hizmetlerinin daha kaliteli ve sağlık hizmeti bedellerinin karşılanabilirliği; iyi eğitimli ve tecrübeli sağlık personeli ve uzman hekimlerle birlikte, hastayla iyi iletişim kurmaları ve hastaya özenli yaklaşım gibi nedenlerden dolayı medikal turizminde önemli bir ülke haline gelmiştir (Gönenç, 2016, s.1175).

Özellikle sağlık turizminin en özellikli grubu olan medikal turistler, sağlık turizmi açısından ayrı ve özel bir öneme sahiptir (Gönenç, 2016, s.1177).

Medikal turizmin nedenleri hukuken de kendi içinde sinıflara ayrılmaktadır. Bu sınıflandırmadan kısaca bahsedecek olursak;

- hastanın hem kendi ülkesinde hem de gittiği ülkede yasal olan tedavi hizmetleri,

- organ satışı gibi her iki ülkede de yasadışı olan hizmetleri ve

- taşıyıcı annelik, kürtaj, ötenazi gibi hastanın kendi ülkesinde yasadışı olan, ancak gittiği ülkede yasal olan sağlık hizmetlerdir. (Cohen, 2010, s.1477).

Bu çalışmada her iki ülkede de yasal olan medikal turizme ilişkin hizmetlerden kaynaklanan özel hayatın gizliliği ve mahremiyet konusu ele alınmıştır.

\subsection{Sağlık Turizminde Aracı Kurumlar}

Sağlık turizmi birden çok paydaşa sahip olması nedeniyle büyük bir endüstridir. Sağlık turizmi endüstrisi, "sağlık kuruşlarının yanısıra aracı

\footnotetext{
${ }^{5}$ Bakınız Ekonomi Bakanlığı, "2015/8 Sayılı Döviz Kazandırıcı Hizmet Ticaretinin Desteklenmesi Hakkında Karar"
} 
kurumlar, konaklama merkezleri, pazarlama, iletişim ve ulaşım" gibi alt sektörlerle beraber bir bütünlük arz edip, bu özelliği itibariyle bu sektörlerdeki her değişimden ve yasal değişikliklerden etkilenmektedir (Aslanova, 2013, s.33). Sağlık turisti, sağlık hizmet kuruluşu ile durumuna göre "tedavi sözleşmesi veya hastaneye kabul sözleşmesi; ulaşım için hava veya karayolu şirketi ile taşıma sözleşmesi; konaklama için otel veya pansiyon ile barındırma sözleşmesi yapmaktadır". Ayrıca tüm bu ilişkilerin kurulmasına "aracılık" etmesi amacıyla bir aracı kurum ile de anlaşma yapabilmektedir (Uyanık, 2015).

Sağlık Turizmi Kurulu' nun (SATURK) yayınladığı raporda, aracı kurum; "sağlık turizminde yabancı hasta ile sağlık kuruluşu arasındaki ilk ilişkinin kurulmasında yardım eden, ilişkileri koordine edip, hastanın tüm tıbbi kayıtların özel sağllk kuruluşuna ileten önemli bir fonksiyona sahip paydaş" olarak tanımlanmıştır. Aracı kurumlar, genellikle yurt dışında ofisler açarak ya da internet üzerinden pazarlama yaparak elde ettiği hasta bilgilerini, temsilcileri tarafından merkeze yönlendirmektedir (Sağlık Turizminde Aracı Kurumlar Raporu).

Aracı kurumlar, genellikle internet vasıtasıyla, sağlık turizminden faydalanmak isteyen hastaların gidebilecekleri potansiyel yerler konusunda bilgi sahibi olmalarını sağlamakta; olanakları, hizmet tedarikçileri ve prosedürleri anlatmaktadırlar. Bu yolla, aracı kurum ile hasta kişisel bilgilerini paylaşmaktadır (Aydın ve Karamehmet Aydın, 2015, s.50).

Böylesine önemli bir fonksiyona sahip olan sağlık turizminde aracı kurum olarak adlandırılan bu paydaşın yasal dayanağı, Sağlık Turizmi Yönetmeliği madde 4/g' de; "Bakanlıkça, uluslararası sağlık turisti ile beraberindeki refakatçi ve diğer yakınlarına konaklama, ulaşım ve transfer hizmetlerinin sağlanması faaliyetlerini yürütmek üzere yetkilendirilen, 14.9.1972 tarihli ve 1618 sayıl Seyahat Acentaları ve Seyahat Acentaları Birliği Kanunu uyarnca işletme belgesi alan A grubu seyahat acentaları..," olarak belirlenmiştir. Yani aracı kurum olarak adlandırılan bu kurumlar, sağlık sektörüyle doğrudan bağı olmayan, turistik faaliyet icra eden işletmelerdir. Bu işletmeler, Yönetmeliğin madde 5/1'de "Uluslararası sağlık turizmi kapsamında faaliyette bulunabilmek için; sağllk tesisinin ve aracı kuruluşun uluslararası sağlık turizmi yetki belgesi almasını zorunlu" kılmıştır. 


\section{Hastanın Özel Hayatının Gizliliği ve Mahremiyet Hakkı}

\subsection{Terim Sorunu}

"Mahremiyet" ve "özel hayat" terimleri zaman zaman birbiri yerine kullanılan iki kavramdır. Arapça "yasak, tabu, dokunulmaz" anlamına gelen ve "haram" kelimesinden türetilen ve sözlük anlamı "gizlilik" olan "mahremiyet" sözcüğü, yanlış bir biçimde "özel hayat" ile eş anlamlı olarak kullanılmaktadır (Salihpaşaoğlu, 2013, s.233).

"Mahremiyet" kavramı, Büyük Türkçe Sözlükte "başkalarına söylenmeyen, gizli" olarak tanımlanmaktayken; "Özel Hayat" kavramı ise "kişinin kendine özgü yaşayışı, yaşama tarzı, kendisini ilgilendiren tutum ve davranışı" olarak tanımlanmıştır (Türk Dil Kurumu, Büyük Türkçe Sözlüğ̈̈).

Özel hayat ve mahremiyet kavramı, çerçeve bir kavram olan "kişilik hakkı" kavramının altında incelenmekte (Çaykent, 2014, s.2), özel hayatın mahremiyeti de kapsadığı genel olarak kabul edilmektedir. Özel hayat, kişinin güven duyarak paylaştığı, diğer kişilerin bilgisinden uzak tuttuğu ve diğer kişiler tarafından öğrenilmesini istemediği bir "giz alanı" ve kişinin bu giz alanına dâhil etmememekle beraber sadece kendisine yakın kişilerle paylaştığı ve bunların dışındaki kişilere gizli kalmasını istediği “özel alanı" da içermektedir (Salihpaşaoğlu, 2013, s.233). Mahremiyet ise bireyin diğer bireyler tarafından ne ölçüde tanınıp bilindiği ve diğer bireylerin fiziksel olarak bireye ne ölçüde ulaşabilir oldukları ile yakından ilişkilidir (Yüksel, 2009, s. 278). Mahremiyet ve özel hayat arasındaki fark ise mahremiyet bir yakınlık ve gizlilik sınırı koymaktayken; özel hayat kavramı kişilerin kendileri için, kendilerine dair kurdukları alan ve buna dair bir hak olarak ortaya çıkmaktadır (Çaykent, 2014, s.2).

Mahremiyet, temel anayasal hakları kapsayan olağanüstü geniş kapsamına rağmen üzerinde henüz yeterince tartışılmamış meseleleri de kapsayan bir terimdir (Cate, 2003, s.2). 1890 yılında "Harvard Law Review" da yayınlanan "Mahremiyet Hakkı" (The Right to Privacy) adlı makalelerinde Warren ve Brandeis, değişen siyasi, sosyal ve ekonomik 
nedenlerden dolayı hayat, mülkiyet, hürriyet haklarının korunması ilkesinin yeniden tanımlanması gerektiğini belirtmişlerdir. Makele'de, "Hayat Hakkı" nın kişinin sadece bedenine ve vücut bütünlüğüne yönelik yapılan her türlü saldırı ve kötü muamelelerden koruma anlamında tanımlanamayacağını; hayat hakkı ile hayatını sürdürme ve yalnız bırakılma hakkını da anlamak gerektiğini vurgulamış (Warren ve Brandeis, 1890, s. 193) ve yalnız bırakılma hakkı ile mahremiyet hakkına işaret etmiştir..

Gavisont, mahremiyet konusundaki endişemizin, başkaları tarafından ne ölçüde tanındığımız; başkalarının bize fiziksel olarak erişebilme derecesini ve başkalarının ilgisine ne ölçüde maruz kaldığımıza ilişkin olduğunu; ayrıca, farklı gerekçelere dayansa bile gizlilik talebimizin nedenlerinin benzer olduğunu; özgürlük, özerklik, benlik ve insan ilişkilerinin geliştirilmesi gibi hayatımızdaki mahremiyetle ilgili işlevlerle ilgili olduğuna dikkat çekmiştir (Gavisont, 1980, s. 423).

Felsefi anlamılla mahremiyet kavramı ise "bireyin tikel ve bağımsız bir varlık olduğu ve bu bağlamda bireyin kendi benlik bilincinin farkında olarak otonomi sahibi olduğu ve diğer bireylere karşı sahip olunan dokunulmayacak ve bağımsız varlık alanının tikel varoluşun onaylanması anlamında mahremiyet kavramının dayanağını oluşturduğu" şeklinde ifade edilebilir (İzgi, 2014, s. 26). Bir başka deyişle mahremiyet, yalnızca kişinin yakından ilişki kurduğu kişilerle arasındaki ilişkinin açığa çıkmaması gerektiği şekilde yorumlanmamalıdır. Aynı zamanda, tek başına kendi seçimlerini yapabilmesi, düşünce ile birlikte davranışlarını özgürce oluşturabilmesi ve bunları yaşamında uygulayabilerek, kendisine dair bilgilerle birlikte başkaları ile olan ilişkilerini tek başına düzenleyebilmesidir (Yüksel, 2009, s.29). Mahremiyeti toplumdan soyutlanma olarak değil, kişi ile onun dışındakilerin sınırının belirlenmesi, kontrol edilmesi olarakta ifade edebiliriz (İzgi, 2014, s.27). Bu bağlamda da birey, kendine ait bilgileri açıklama zaman ve şekli konusunda en yetkili kişi konumunda bulunmalıdır (Kaya, 2011, s.20). O halde mahremiyeti, "insanın varoluşu için ötekinin belirlenimine gereksinim duymama durumu olduğunu" ifade edebiliriz (İzgi, 2014, s.26).

Mahremiyetten daha geniş bir kavram olduğunu ifade etttiğimiz “özel hayat" kavramının ne olduğuna ilişkin açık tanımlar olmamasına rağmen, özel hayatın içeriğine ilişkin yaklaşımlardan bir tanıma ulaşabiliriz. Bazı yazarlar, özel hayatın gizli ya da dokunulamaz, 
ulaşılmaz yönünü öne çıkartarak özel hayatı tanımlamışlardır (Dinç,1987/2, s.195: Özsunay, 1979, s.127: Şen, 1996,s.5: Kaboğlu, 2002, s. 292). "Kişinin sadece kendisi için saklı tuttuğu ve başkalarının bilgisinden uzak kalmasını istediği, özel araştırma ve bilgi edinmeyle sağlanan kişiye ait hususlar" şeklinde tanımlayabileceğimiz bu yaklaşımla (Korkmaz, 2014, s.100) kişinin gizli kalmasını, dokunulamaz ve ulaşılmaz olmasını dilediği maddi ve manevi unsurlara sahip olduğu özel hayatının bu kesitinde kişi yaşadıkları ve ayrıca yaptıkları ile ilgili bilgilerin başka kişilerce bilinmesini istememektedir. Özel hayatın bu boyutu bireyin gizli ve bağımsız alanını oluşturmaktadır (Sert, 2008, s.37). Özel hayata ilişkin olarak "bağımsızlık" ve "gizlilik" iki temel ilke olarak kabul edilmektedir. Geniş anlamıyla bağımsızlık, kişinin yaşam tarz ve davranışları ile birlikte ilişkilerini tercih etme hakkını ifade ederken; gizlilik ise başkalarının merak alanı dışında kalabilmesini ve bireyin ve aile çevresinin dışarıdan gelecek müdahalelere karşı mahremiyetinin sağlanmasını ifade etmektedir (Yüksel, 2003, s.187).

İnsan Hakları Avrupa Komisyonu, özel hayatı, "bireyin hayatını istediği gibi aleniyetten uzak yaşaması ve bireyin kendi kişiliğini geliştirmesi için özellikle de manevi alanda diğer insanlarla ilişki kurması ve geliştirmesi" şeklinde tanımlamıştır (Sert, 2008, s. 36).

Üzeltürk ve Özsunay özel hayatının gizliliği çerçevesinde, “kişinin toplum içindeki değerleri içinde adı, görüntüsü, şeref ve haysiyeti bağlamında korunan bir kavram" olduğuna dikkat çekerek, bu hakkın hukuki temelinin insan onuru olduğuna işaret etmişlerdir (Üzeltürk, 2004, s.169; Özsunay, 1979, s.148-149).

Bireyin, özel hayatına dair başka insanlar ile yaptığı paylaşım ve bu paylaşımın yoğunluğuna göre iç içe geçmiş çemberlere benzetilmektedir. İşte bu çemberlerden en içte bulunanı, kişinin yakınlarıyla dahi paylaşmadığı ve sadece kendisi ile baş başa kaldığ 1 "çekirdek alan" olarak adlandırılmaktadır. Bu çekirdek alandan dışarıya doğru, kişinin başka çevrelere yönelik olarak paylaşım derecesini giderek arttırdığı başka çemberler bulunmaktadır (Araslı, 1979, s.3).

Tüm bu açıklamalarla beraber özel hayata ilişkin uluslararası belge ve sözleşmelerde söz konusu hakkı ifade etmek için bazen "özel hayat"(private life), (İnsan Haklarının ve Temel Özgürlüklerin Korunmasına İlişkin Avrupa Sözleşmesi, m.8) bazen de "mahremiyet" (privacy) (İnsan 
Hakları Evrensel Beyannamesi, m.12; Medeni ve Siyasi Haklara Dair Uluslararası Sözleşme, m.17) terimi kullanılmaktadır (Salihpaşaoğlu, 2013, s.233).

Özel hayat ve mahremiyetle ilişkili bir başka kavram ise "kişisel veri" kavramıdır. Bireyin kendine ait bilgilerin denetimini elinde tutması hem özel hayatınının gizliliğini hem de mahremiyetini koruma bakımından önemlidir. Bireyin kişisel verileri üstündeki denetim yetkisini kaybetmesi bireyin özgürlük ve özerklikle beraber mahremiyetinin kısaca "ben" olma özelliğinin kaybedilmesi anlamına gelecektir (İzgi, 2014, s.29).

"Kişisel verilerin korunması" kavramı hukuk dünyasında yeni bir kavram olmakla birliktei kaynağını mahremiyet gibi oldukça eski ve köklü bir kavramdan almaktadır (Dülger, 2015.s.46). Bu kavrama ilişkin uluslararası insan hakları belgesinde özel bir düzenlemeye rastlanmasa da, kişisel verilerin korunmasının altında mahremiyet anlayışı bulunduğu için, özel yaşamın korunmasına dair düzenlemelerin ayrıca kişisel veriler üzerinde de etkiye sahip olduğu görülmektedir (Dülger, 2015.s.46). Kişisel verilerin korunması, özel hayatın gizliliği ve korunması hakkının bir yansıması olarak kabul edilerek çoğu ülkede kişisel verilerle bağlantı kurulmadan, özel hayatın gizliliği hakkının tanımlanamadığı görülmüştür (Çelik, 2017, s.391).

Kişisel veri, 6698 Sayılı Kanunun m.3/d de "Kimliği belirli veya belirlenebilir gerçek kişiye ilişkin her türlü bilgi" olarak tanımlanmıştır. Belirlenebilir kişiden kasıt ise uygun araçlar yardımıyla doğrudan veya dolaylı bir şekilde özellikle bir kimlik numarasına veya o kişinin fiziksel, psikolojik, zihinsel veya sosyo-ekonomik kimliğine atıfla belirlenen bir kişidir (Keser Berber; Ülgü ve Er, 2009, s.120).

Kişisel verilerin korunmasındaki amaç ise bireylerin özel hayatının gizliliğini güvence altına alma yoluyla kamu veya özel sektör tarafından tutulan kayıtların korunmasını sağlayarak kişileri korumaktır (Çelik, 2017, s.392).

Kişisel verilere ilişkin ilk uluslararası belge olan ve Ekonomik İşbirliği ve Kalkınma Teşkilatı (OECD) tarafından düzenlenen 1980 tarihli "Mahremiyetin ve Kişisel Verilerin Sinırlararası Aktarımının Korunması Hususunda OECD Rehber İlkeleri" nin "Genel Tanımlar başlığı altında yer alan 1. maddesinde kişisel veri kavramı, "belirlenmiş veya belirlenebilir olan gerçek bir kişiye ilişkin her türlü veri" olarak tanımlanmıştır. 
Kişinin belirlenemez hale getirilmesi ise anonim veri denilen, "kişisel verilerin, başka verilerle eşleştirilerek dahi hiçbir suretle kimliği belirli veya belirlenebilir bir gerçek kişiyle ilişkilendirilemeyecek hâle gerilmesi" halidir (Kişisel Sağlık Verilerinin İşlenmesi ve Mahremiyetinin Sağlanması Hakkında Yönetmelik m.4/1-a). Verilerin anonimleştirilmesi daha çok araştırma, planlama, istatistikleştirme vb. gibi çalışmalarda herhangi bir kişiye işaret etmekten ziyade büyük bir data olarak çıkan bu tür veriler, ilgili kişilerle ilişkilendirilmeleri olası olmadığından kişisel veri olarak kabul edilememelidir (Dülger, 2015, s.50). Kişisel veri kavramına ilişkin Yargıtay Ceza Genel Kurulu'nun güncel bir kararında kişisel veri: “...kişinin; Türkiye Cumhuriyeti kimlik numarası, adı, soyadı, doğum tarihi, doğum yeri, nüfusa kayıtlı olunan yer (İl, İlçe, mahalle veya köy), anne ve baba adı, medeni hali (Evli, bekâr, boşanmış), nüfusa kayıtlı olduğu cilt ve aile sıra no, kan grubu, evlenme tarihi, boşanma tarihi ve mahkeme kararı bilgileri, adı-soyadı veya diğer kayıt düzeltmeleri, vatandaşlıktan çıkarılma bilgileri, evlatlık ilişkisi, adresi, dini, bitirilen okullar (ilk-orta-yüksek), hastalıkları, hastalıklarn ile ilgili tahlil sonuçları (DNA bilgileri), mali durumu (servet, aldığı ücretler), ahlaki eğilimleri, zaafları, çevre ile ilişkileri, hatıra, anı ve günlükle ilgili defterindeki bilgileri, siyası görüşü (oy verdiği partiler, üye olduğu dernekler), alışkanlıkları, sevdiği kitaplar veya gazeteler, alışveriş eğilimleri, vergi numarası, e posta adresi ve şifresi, banka bilgileri, bilgisayarmın IP numarası, emeklilik ve kurum sicil numarası, aldığı ödüller, parmak izi, avuç içi izleri, mektupları, yazıları, kitapları, telefon numaraları, mesajları, fiziki kimliği (boy, kilo, engellilik durumu, ten rengi, göz rengi, saç rengi ve şekli, sesi, genel görünüm, ayak ve beden numarası ve çok daha fazla bilgi kişisel veri kapsamında değerlendirilebilecektir..." şeklinde geniş bir bağlamda tanımlamıştır (Ceza Genel Kurulu 17.06.2014, 2012/12-1510 E, 2014/331 K.).

Kişisel verilerin korunmasına ilişkin olarak “hassas kişisel veriler (sensitive data)" veya "özel nitelikli kişisel veri kavramı" 6 da önemli bir yere sahiptir (Aydın, 2014, s.6). Hassas kişisel veriler, "1rkı ve etnik köken, ten rengi, siyasi görüşleri, dini ve felsefi inançlar, sendika üyelikleri, sağlık

\footnotetext{
${ }^{6} 6698$ sayılı "Veri Koruma Kanunu ve Kişisel Sağlık Verilerinin Işlenmesi ve Mahremiyetinin Sağlanması Hakkında Yönetmelikte" kişisel sağlık verileri için hassas veri yerine özel nitelikli veri ifadesini kullanılmaktadır.
} 
durumu, cinsel yaşam, mahkûmiyet geçmişi vb. durumları ortaya koyan durumlar" olarak tanımlanabilir (Kaya, 2011, s.318).

Kişisel verilerin korunması uluslararası hukuk bakımından temel bir insan hakkı olarak kabul görmekteyken; ulusal hukuk bakımından ise Anayasa normu ile düzenlenmiş temel bir hak ve özgürlük olarak değerlendirilmektedir. Doktrinde ise kişisel verilerin, "özel hayatın gizliliğinin korunması " başlığı altında bir alt başlık olarak mı ele alınması gerektiği; yoksa kendi başına bağımsız bir kavram olarak mi değerlendirilmesi hususunda bir tartışma bulunmaktadır (Dülger, 2015, s.44). Her ne kadar kişisel verilere, özel hayatın gizliliği hakkının klasik yaklaşımıyla yaklaşılmasının teknolojik alanda yaşanan ilerlemeler karşısında yetersiz kaldığı, kendine has bazı gereklilikleri nedeniyle ayrı bir alan olarak incelenmesi gerektiği ileri sürülmekteyse de (Elmalıca, 2016, s.1610) biz bu çalışmada kişisel verilerin korunmasını ayrı bir başlık altında değil, özel hayatın gizliliği ve mahremiyet hakkı içinde alt bir kavram olarak ele alıp inceleyeceğiz.

\subsection{Uluslararası Sözleşmelerde Özel Hayatın Gizliliği ve Mahremiyet Hakk1}

1948'den itibaren uluslararası alanda insan haklarını ve normların belirleyen "İnsan Hakları Evrensel Beyannamesi" (İHEB), tüm insanların özgürlük, haysiyet ve haklar bakımından eşit doğdukları temel değeri üzerine kuruludur. Bireye saygı duyulması ve her türlü ayırımcılığın yasaklanması tüm insan hakları çalışmalarının ana konusudur ( $\mathrm{Ru}-$ benson, 2002, s.5).

İHEB'in 12. maddesi özel hayata saygı hakkı ile ilgilidir. "Kimsenin özel yaşamına, ailesine konutuna ya da haberleşmesine keyfi olarak karışılamaz, şeref ve adına saldırılamaz. Herkesin bu gibi karışma ve saldırllara karşı yasa tarafından korunmaya hakkı vardır". Madde özel hayatın korunmasını şeref ve haysiyetle ilişkilendirmiştir.

"Medeni ve Siyasal Haklar Uluslararası Sözleşmesi" m. 17' de mahremiyet hakkı"; "1. Hiç kimsenin özel ve aile yaşamına, konutuna veya haberleşmesine keyfi veya hukuka aykır olarak müdahale edilemez; onuru veya itibarı hukuka aykırı saldırılara maruz bırakılamaz. 
2. Herkes bu tür saldırllara veya müdahalelere karşı hukuk tarafindan korunma hakkına sahiptir" şeklinde düzenlemiştir. Görüleceği üzere bu düzenleme İHEB ile neredeyse aynı içeriğe sahip bir düzenlemedir.

1991 tarihli Birleşmiş Milletler (BM) "Çocuk Hakları Sözleşmesi” m.16 da özel hayata saygı hakkı konusunda "Medeni ve Siyasi Haklar Sözleşmesi”ne benzer düzenlemeler getirmektedir. "İnsan Hakları Amerikan Sözleşmesi"nin m.11/2,a "Afrika İnsan ve Halkların Hakları Şartı" m.29 da özel hayatın korunmasını düzenlemektedirler. Bunlar da yazılabilir.

Avrupa İnsan Hakları Sözleşmesinin 8. maddesinde, "Özel Yaşamın ve Aile Yaşamının Korunması" başlığını altında;

"1. Herkes özel ve aile hayatına, konutuna ve yazışmasına saygı gösterilmesi hakkına sahiptir.

2. Bu hakkın kullanılmasına bir kamu makamının müdahalesi, ancak müdahalenin yasayla öngörülmüss ve demokratik bir toplumda ulusal güvenlik, kamu güvenliği, ülkenin ekonomik refahı, düzenin korunması, suç işlenmesinin önlenmesi, sağlığın veya ahlakın veya başkalarının hak ve özgürlüklerinin korunması için gerekli bir tedbir olması durumunda söz konusu olabilir." hükmüne yer verilmiştir.

1997 tarihli Biyoloji ve Tıbbın Uygulanması Bakımından İnsan Hakları ve İnsan Haysiyetinin Korunması Sözleşmesi: İnsan Hakları ve Biyotıp Sözleşmesi" (Biyotıp Sözleşmesi) 10. maddesi özel hayat ve bilgilendirilme hakkı ile ilgilidir.

Avrupa Hasta Hakları Şartı (AHHŞ) önceki uluslararası belgelerde yer alan hasta haklarına ek yeni haklara yer vermiştir. Şart'ta mahremiyet ve gizlilik hakkı düzenlenmiştir.

Amerika Birleşik Devletleri'nde 1966 yılında "Bilgi Edinme Hakkı Kanunu" (The Freedom of Information Act) ile 1974 tarihli "Özel Yaşamın Gizliliği Kanunu" (The Privacy Act) kişisel nitelikli hassas verilere yönelik doğrudan bir koruma getirmiştir (Kaya, 2011, s.321).

Kişisel verilerin korunmasına yönelik ilk uluslararası çalışma OECD'nin 1980 yılında yayınladığı "Mahremiyetin ve Kişisel Verilerin Sınırlararası Aktarımının Korunması Hususunda OECD Rehber İlkeleri" dir. Bu rehber ilkeler "veri toplamanın sınırlı olması, verinin niteliği karşılaması, verinin toplanma amacının belirliliği ve amacı ile bağlılı̆̆ı, 
verinin kullanımının sınırlı olması, veri güvenliği, açıklık, bireyin katılımı ve hesap verilebilirliktir" (Borazan, 2015, s.2015).

Avrupa Konseyi tarafından kişisel verilerin korunmasına yönelik birden fazla metin kabul edilmiştir. Bu metinler içinde kişisel verilerin korunmasına yönelik çalışmalardan en önemlisi Avrupa Konseyi tarafından hazırlanan ve 28 Ocak 1981 yılında kabul edilip 1 Ekim 1985 tarihinde yürürlüğe giren "108 sayılı Kişisel Nitelikteki Verilerin Otomatik İşleme Tabi Tutulması Karşısında Kişilerin Korunmasına Dair Sözleşme" dir (108 Sayılı Avrupa Konseyi Sözleşmesi). Bu Sözleşme, Türkiye tarafından 2016 yılında onaylanıp yürürlüğe girmiştir.

Sözleşmesinin 6. maddesinde, "hassas kişisel veriler" düzenlenmiş olup maddeye göre; "ırksal köken, siyasi görüş ya da dini veya diğer inançlar, sağllk veya cinsel yaşama ilişkin kişisel verilerin, iç hukukta gerekli önlemlerin alınmış olması durumu dışında, otomatik olarak işlenemeyeceğ $i$ " hüküm altına alınmıştır. Sözleşmenin önemi, kişisel verilerin korunması hususunda bağlayıcılığı olan ilk uluslararası hukuki düzenleme olmasıdır. Düzenleme zaman zaman güncellenmiş olup bu güncellemeler arasında "telekomünikasyon hizmetlerinde kişisel verilerin korunması (4 sayılı Tavsiye Karar1 - 1995), tıbbi verilerin korunması (5 sayılı Tavsiye Kararı - 1997), istatistik amaçlı kayıt altına alınan kişisel verilerin korunması (18 sayılı Tavsiye Kararı - 1997), internet ağlarında kişisel verilerin korunması (5 sayılı Tavsiye Kararı - 1999), arama motorları üzerinde insan haklarının ve kişisel verilerin korunması (3 sayılı Tavsiye Kararı - 2012) ve sosyal ağ hizmetleri üzerinde insan haklarının ve kişisel verilerin korunması (4 sayılı Tavsiye Kararı - 2012)" vb. kararlar yer almaktadır (Kutlu ve Kahraman, 2017, s.51-52).

Avrupa Birliği'nin 24 Ekim 1995 tarihinde, 95/46 sayılı “Kişisel Verilerin İşlenmesinde Gerçek Kişilerin Korunması ve Bu Verilerin Serbest Dolaşımı" (AB Veri Koruma Direktifi) başlığı altında düzenlenen Birliğin veri koruma hukukunun temelini oluşturan Yönergesi, Birlik içinde tek bir veri koruma hukukunun temelini oluşturmaktadır. Yönerge ile, her üye ülkedeki kişisel verilerin aynı düzeyde korunmasının garanti altına alınması amaçlanmıştır (Dülger, 2015, s.48). Ayrıca birinci maddesi de üye devletlerin, gerçek kişilerin temel hak ve özgürlükleri ile beraber özellikle kişisel verilerin işlenmesine yönelik olarak özel yaşamın gizliliği hakkını korumalarını hedefleyerek, kişisel verilerin korunmasının temel 
bir insan hakkı olduğunu kabul etmesi bakımından önemlidir (Kutlu ve Kahraman, 2017, s.52). Bu direktif, yerine "General Data Protection Regulation" (GDPR) 25 Mayıs 2018 tarihinde yürürlüğe girmiştir. GDPR ile AB ülkelerinde yer alan 28 farklı Veri Koruma Kanunları ilga olmuştur (İmamoğlu, 2017, s.6).

\subsubsection{Türk Hukuk Sisteminde Özel Hayatın Gizliliği ve Mahremiyet Hakk1}

1982 Anayasası'nın “Temel Haklar ve Ödevler" başlıklı ikinci kısmının ikinci bölümünde "Kişinin Hakları ve Ödevleri" başlığı altında "Özel Hayatın Gizliliği ve Korunması" ele alınmıştır. 20, 21 ve 22. maddeleri özel hayatın gizliliğinin korunması çerçevesinde hükümler içermektedir. 20. madde özel hayatın gizliliği ve korunmasına ilişkin olup bu maddeye 2010 yılında eklenen ek fikra ile "herkesin kendisiyle ilgili kişisel verilerin korunmasını isteme hakkına sahip olması" sağlanmıştır. Buna göre m.20/3

"Herkes, kendisiyle ilgili kişisel verilerin korunmasın isteme hakkına sahiptir.Bu hak; kişinin kendisiyle ilgili kişisel veriler hakkında bilgilendirilme, bu verilere erişme, bunlarn düzeltilmesini veya silinmesini talep etme ve amaçlar doğrultusunda kullanılıp kullanılmadığını öğrenmeyi de kapsar. Kişisel veriler,ancak kanunda öngörülen hallerde veya kişinin açık rızasıyla işlenebilir. Kişiselverilerin korunmasına ilişkin esas ve usuller kanunla düzenlenir." Bu düzenleme ile birlikte kişisel verilerin korunması temel insan hakkı olarak kabul görmüş ve Anayasa ile güvence altına alınmıştır. Ayrıntılar ise kişisel verilere ilişkin olarak çıkarılacak kanuna bırakılmıştır (Çelik, 2017, s. 395).

Anayasa'da açıkça yer aldığı üzere "kişilerin kendileri ile ilgili bilgilerin korunmasını isteme hakkı bulunmakta" olup bunun istisnası ise; kişinin rıza göstermesi ya da yasanın istisnayı açkça öngörmüş olması halleridir (Uyanık, 2015, s.85). Bu düzenlemeye binaen 6698 Sayılı "Kişisel Verilerin Korunması Kanunu" (KVKK) 2016 yılında yayımlanarak yürürlüğe girmiştir. Bu kanunun yapılmasında “AB Veri Koruma Direktifi"' nin de örnek alındığı görülmektedir (Zeybek Ünsal ve Örnek Büken, 2018, s.83). 6698 Sayılı Kanun'un amacı, “kişisel verilerin işlenmesinde başta özel hayatın gizliliği olmak üzere kişilerin temel hak ve 
özgürlüklerini koruma ve kişisel verileri işleyen gerçek ve tüzel kişilerin yükümlülükleri ile uyacakları usul ve esasları" düzenlemektir.

Özel hayatın korunması çerçevesinde "Türk Medeni Kanunu" (MK) ve "Türk Borçlar Kanunu" (BK) da çeşitli hükümler içermektedir. MK' da kişinin özel hayatının korunmasını ve dokunulmazlığını sağlamaya yönelik m. 23, kişilerin kişilik haklarına dokunulamayacağı ifade edilirken özel hayatlarına da dokunulmayacağı düzenlenmiştir. Yine BK'nın 49. maddesi kişilik haklarını içeren hükümler düzenlenmiştir.

Kişisel verilerin korunmasına ilişkin olarak 5237 sayılı Türk Ceza Kanunu'nun (TCK) özel hükümlerin yani suç tiplerinin düzenlendiği ikinci kitabının "kişilere karşı suçlar" başlıklı ikinci kısmının "özel hayata ve hayatın gizli alanına karşı suçlar" başlıklı dokuzuncu bölümünde yer almaktadır. TCK'nın 135. maddesinde "kişisel verilerin kaydedilmesi suçu", 136. maddesinde "verileri hukuka aykırı olarak verme veya ele geçirme suçu", 137. maddesinde bu suçların nitelikli halleri, 138. maddesinde "verilerin yok edilmemesi suçu" 140. maddesinde ise bu suçlara ilişkin olarak tüzel kişiler hakkında uygulanacak güvenlik tedbirleri düzenlenmiştir (Dülger, 2016, s.119). Bu suç tipleriyle kişisel verilerin mi yoksa sır kapsamına giren bilgilerin mi korunduğu sorusu akla gelmektedir. TCK'nın 135. ve 136. maddelerinde kişisel verilerin hukuka aykırı olarak kaydedilmesi ve bu verilerin hukuka aykırı bir biçimde verilmesi veya ele geçirilmesi aranmakla birlikte söz konusu verilerin "sır" kapsaminda değerlendirilen ve sahibinin diğer kişilerin erişimine ve öğrenmesine izin vermediği veri niteliğinde olması aranmamaktadır (Dülger, 2016, s.121).

Ayrıca Türk Yüksek Mahkemelerinin de özel hayatın gizliliği ve korunmasına ilişkin kararları bu konuda yol göstericidir . ${ }^{7}$

\footnotetext{
${ }^{7}$ Anayasa Mahkemesi 31.03.1987 gün ve E: 1986/24, K: 1987/ "....Özel hayatın korunması her şeyden önce bu hayatın gizliliğinin korunması, başkalarının gözleri önüne serilmemesi demektir. Orada cereyan edenlerin yalnız kendisi veya kendisinin bilmesini istediği kimseler tarafından bilinmesini istemek hakkı, kişinin temel haklarından biridir. Bu niteliği sebebiyledir ki, özel hayatın gizliliğine dokunulmaması, insan haklarına ilişkin beyanname ve sözleşmelerde korunması istenilmiş, ayrıca tüm demokratik ülke mevzuatında açıkça belirlenen istisnalar dışında bu hak devlet organlarına, topluma ve diğer kişilere karsı korunmuştur. Insanın mutluluğu için büyük önemi olan özel hayata saygı gösterilmesi hakkı onun kişiliği için temel bir hak olup yeteri kadar korunmadığı takdirde kişilerin ve dolayısıyla toplumun kendini huzurlu hissedip güven içinde yasaması mümkün değildir. Bu nedenlerle söz konusu gizliliği çeşitli biçimde ihlal eylemleri suç sayılarak ceza yaptırımlarına bağlanmıştır".
} 


\subsection{Uluslarası Bildirge ve Sözleşmelerde Hastanın Özel Hayatının Gizliliği ve Mahremiyet Hakkı}

Sağlık hizmetlerinden faydalalan kişilerin özel hayatlarına saygı gösterilmesi, bu kişilerin kişilik haklarının ve onurlarının korunması açısından son derece önemlidir. Bu nedenle sağlık hizmetlerinde özel hayatın gizliliği ve mahremiyet hakkı tıp etiği ve hukuku açısından önem arz etmektedir (Sert, 2008, s. 91).

Sağlık hizmetlerinde özel hayatın gizliliği ve mahremiyet hakkı hekimin ve sağllk personelinin sır saklama yükümlülügü olarak önem kazanmaktadır. Sır saklama yükümlülüğü, Borçlar Kanunu m.502 vd. gereği sağlık çalışanının sadakat yükümlülügünden kaynaklanan bir alt yükümlülüğüdür (Hakeri, 2013, s.495). Sağlık hizmetlerinde mahremiyet ve sır saklama yükümlülüğü kavramları birbiriyle ilişkili kavramlar olmakla beraber, bu kavramları birbirinden ayıran bazı özellikler bulunmaktadır. Sağlık hizmetlerinde mahremiyet, "bireyin kişisel sağlık bilgilerinin toplandığı, kullanıldığı, depolandığı ve aktarıldığı haller üzerindeki denetim yetkisi", sır saklama yükümlülüğü ise "hekim - hasta ilişkisi gibi yakın bir ilişki içerisinde olan iki birey arasındaki güvenin muhafazasına odaklanan, sağlık bilgilerinin mahremiyetinin bir görünümü" olarak tanımlayabiliriz (Dülger, 2014, s.63-64).

Hekim açısından "sır" kavramından anlaşılması gereken yalnızca belirli ve sınırlı sayıdaki kişi tarafından bilinen ve bunun açıklanmamasında hasta açısından korunmaya değer bir yarar ve olgu olup sır kavramının geniş yorumlanması gereklidir (Hakeri, 2013, s.495). Hastaya dair mahremiyet kavramından sadece hastanın hastalığına ilişkin bilgileri değil; hastaya ait kişisel, mesleki, ailevi, ekonomik ve mali durumları da anlamak gereklidir (Sarp, 2011, s.10). Hastaya dair her türlü bilgi, aitlikmülkiyet ilişkileri düzleminde değerlendirilir ve bunların muhafazası ve gizliliği temelde sağlık profesyonellerinin sorumluluğunda olduğu kabul edilmelidir (İzgi, 2014, s.33).

Sağlık hizmetlerinde mahremiyet, "hastanın kişisellik ve gizlilik düşüncesine saygının gelişmesine" ve "tıbbın temel bir amacı olan hastanın sağlık bakımının geliştirilmesine" hizmet etmektedir. Böylece hastanın, kişisel fiziksel ve psikolojik sırları, mahcubiyet ve hassasiyetini azaltmak amaciyla gizli tutulur. Ve bunun bir sonucu olarakta hastanın 
hekimle paylaştı̆̆ı bilgilerinin bir başkasına aktarılmayacağına inanmasına olanak sağlayarak hastaların hekimleriyle dürüst ve açık konuşması teşvik edilmiş olur (İzgi, 2014, s.33).

Sağlık hizmetlerinde özel hayatın gizliliğini ve mahremiyeti korumanın en önemli yöntemi hastanın özel hayatının gizliliğini ve mahremiyetini bir hasta hakkı olduğunu benimseyen sağlık personelinin varlığıdır. Sağlık hizmetlerinin her düzeyinde çalışan sağlık personeli bu konuda yükümlülük taşımaktadır. Hastaya ait tıbbi kayıtlara yalnızca doğrudan ilgili kişiler görebilmeli, diğer sağlık personeli de dâhil olmak üzere başkalarının görmesi ve bu bilgilere erişimi mümkün olmamalıdır (Dülger, 2014, s.60). Diğer taraftan ne yazık ki temel hasta haklarından biri olan "Hastanın Özel Hayatının Gizliliği ve Mahremiyet Hakkı" sağlık çalışanları tarafından en fazla ihlale uğrayan haklardan biri olduğuna yönelik çalışmalar da bulunmaktadır (Teke, Uçar, Demir, Çelen, Karaalp, 2007).

Tarihsel süreç içinde hekimlerin hastaya dair öğrendiği kişisel bilgileri ifşa etmemelerine ilişkin sorumluluk Hipokrat Yemininde de ifade edilmiştir. "Tedavi sırasında ve hatta tedavi sürecinin dışında bile, eğer insanların yaşamı hakkında dışarıya asla yayılmaması gereken bir şey görür ya da duyarsam, bu gibi şeyleri kendime saklayacak ve bunlar hakkında konuşulmasını utanç verici olarak göreceğim" (Veatch, 2010, s.193).

1981 yılında "Dünya Tip Birliği" nin 34. Genel Kurulu'nda, hasta haklarına ilişkin olarak ilk uluslararası belge niteliğinde olan "Lizbon Hasta Hakları Bildirgesi" temel hasta haklarını konu alan altı madde ve hekimlere bunları yerine getirmesi hususunda görev veren bir paragraftan meydana gelmektedir. Bildirgenin d maddesinde hastanın kişisel bilgilerinin gizliliğine saygı gösterilmesi hakkı düzenlenmiştir (Lizbon Hasta Hakları Bildirgesi, 1981).

1994 yılında Dünya Sağlık Örgütü'nün “Avrupa'da Hasta Haklarının Geliştirilmesi Amsterdam Bildirgesi”, Dünya Sağllk Örgütü'ne üye Avrupa ülkelerindeki hasta haklarının gelişimini sağlamaktır. Bildirgenin 4. kısmı mahremiyet ve özel hayata ilişkin düzenlemelere ayrılmıştır (Amsterdam Bildirgesi, 1994).

1995 yılında Bali'de Dünya Tıp Birliği 1981 yılında yayınladığı Lizbon Bildirgesini tekrar gözden geçirerek ve genişleterek yayınlamıştır (Bali Bildirgesi 1995). 
Hasta mahremiyeti konusunda Lizbon Bildirgeleri ve Amsterdam Bildirgelerinde benzer ifadeler yer almakla birlikte Amsterdam Bildirgesi daha ayrıntılı içeriğe sahiptir (Sert, 2004, s.77).

2002 tarihli Dünya Tıp Birliği'nin “Sağlık Veri Tabanları İle İlgili Etik Düşünceler Bildirgesi" ayrıntılı Bildirgede gizlilik hakkının "insanlara bireyler olarak kendileri hakkındaki bilgileri açığa çıkarmayı ve kullanmayı kontrol etmeleri için yetki verdiğini ve bir hastanın kişisel sağlıkla ilgili bilgilerinin gizliliği mahremiyet sorumluluğu olarak hekim tarafindan korunması gerektiği" belirtilmiştir. Ayrıca "hekimleri hastalarına ilişkin tuttukları kişisel sağlık bilgilerinin mahremiyetinden sorumlu olduklarını ve hekimlerin aynı zamanda kişisel sağlıkla ilgili bilginin elektronik ortam da dâhil olmak üzere bilgilerin depolanması, gönderilmesi ya da alınması sırasındaki güvenlik için uygun düzenlemelerin varlığından emin olması gerektiğini" düzenlemiştir (Sayek, 2009, s.177-180).

Biyotıp Sözleşmesi'nin 10. maddesinde sağlığa ilişkin olarak kişisel verilerin korunması ile birlikte kişilerin sağlıklarına dair verileri öğrenme hakkına yer verilmiştir. Maddenin 2. f1krasında ise "herkesin, kendi sağhı̆̆ ile ilgili bilgileri öğrenme hakkı düzenlendikten sonra bireylerin, bilgilendirilmeme isteklerinin de gözetilmesi gerektiği" hükme bağlanmaktadır (Katoğlu, 2006, s.174).

"Avrupa Birliği Temel Haklar Şartı" nın 8. maddesine göre "herkes kendisini ilgilendiren kişisel verilerin korunması hakkına sahiptir."

Dünya Tıp Birliği "Helsinki Bildirgesi"nin 24. maddesi "insanlar üzerinde tıbbi araştırma yürütülürken hastayla ilgili bilgilerinin gizliliğine saygı gösterilmesi” gerektiği "Araştırmalarda kullanılan kişilerin özel yaşamın ve kişisel bilgilerinin gizliliğini korumak için her tür önlem alınmalıdır." şeklinde ifade edilmiştir.

Hasta Haklarına İlişkin "Avrupa Statüsü" nün 6. maddesi de uyarınca hastaya ait bilgilerin gizliliğini konu almıştır.

\subsubsection{Türk Sağlık Mevzuatında Hastaya Ait Bilgilerin Gizliliği ve Mahremiyet}

Türk sağlık mevzuatında özel hayatın korunmasına ilişkin çeşitli yasalarda çok sayıda düzenlemeler bulunmaktadır. Umumi Hıfzıssıhha Kanunu'nun 104. maddesi frengili hastaların bildirimi konusunda hüküm 
içermekle birlikte bulaşıcı hastalığın bildirilmesi sırasında hastanın özel hayatının korunması; hasta ile ilgili bilgilerin açıklanmaması konusu özellikle vurgulanmıştır.

Tibbi Deontoloji Tüzüğü'nün 4. maddesinde "hekim ve diş hekimlerinin mesleklerini icra etmeleri nedeniyle öğrendikleri sırları açıklamalarını yasaklamış ve bilimsel çalışmalarda hastanın kimliğine ait bilgileri saklamaları" emredilmiştir.

Türk Tabipler Birliği tarafından kabul edilen "Hekimlik Meslek Etiği Kuralları" içinde m. 9'da "sır saklama yükümlülüğü" düzenlenmiştir. Hekimin, mesleğini uygularken hastasından öğrendiği bilgileri açıklayamayacağı düzenlenmiştir. Ayrıca hastanın ölmesi ya da ilgili hekimle ilişkisinin sona ermesi halinde dahi hekimin bu yükümlülüğünün devam edeceği düzenlenmiştir.

1998 tarihli "Hasta Hakları Yönetmeliği" nin 21.maddesinde "Mahremiyete Saygı Gösterilmesi" başlığıyla hastanın mahremiyet hakkı düzenlenmiştir.

m.21."Hastanın, mahremiyetine saygı gösterilmesi esastır. Hasta mahremiyetinin korunmasını açıkça talep de edebilir. Her türlü tıbbi müdahale, hastanın mahremiyetine saygı gösterilmek suretiyle icra edilir.

Mahremiyete saygı gösterilmesi ve bunu istemek hakkl;

a) Hastanın, să̆lık durumu ile ilgili tıbbi değerlendirmelerin gizlilik içerisinde yürütülmesini,

b) Muayenenin, teşhisin, tedavinin ve hasta ile doğrudan teması gerektiren diğer işlemlerin makul bir gizlilik ortamında gerçekleștirilmesini,

c) Tıbben sakınca olmayan hallerde yanında bir yakınım bulunmasına izin verilmesini,

d) Tedavisi ile doğrudan ilgili olmayan kimselerin, tıbbi müdahale strasinda bulunmamasinı,

e) Hastalı̆̆ın mahiyeti gerektirmedikçe hastanın şahsi ve ailevi hayatına müdahale edilmemesini,

f) Să̆lık harcamalarının kaynă̆ının gizli tutulmasını, kapsar.

g) Ölüm olayı, mahremiyetin bozulması hakkını vermez. 
Hastanın mahremiyet hakkı çerçevesinde ele alınabilecek diğer bir konu da Hasta Hakları Yönetmeliği m. 23' te düzenlenmiştir. Bu maddede hastaya ait kişisel verilerin gizliliğinin sağlanması ile ilgili düzenleme yer almaktadır.

m.23. "Sağlık hizmetinin verilmesi sebebiyle edinilen bilgiler, kanun ile müsaade edilen haller dışında, hiçbir şekilde açıklanamaz.

Kişinin rızasına dayansa bile, kişilik haklarından bütünüyle vazgeçilmesi, bu hakların başkalarına devri veya aşırı şekilde sinırlanması neticesini doğuran hallerde bilginin açıklanması, bunları açıklayanın hukuki sorumluluğunu kaldırmaz.

Hukuki ve ahlaki yönden geçerli ve haklı bir sebebe dayanmaksızın hastaya zarar verme ihtimali bulunan bilginin ifşa edilmesi, personelin ve diğer kimselerin hukuki ve cezai sorumluluğunu da gerektirir.

Araştırma ve eğitim amacı ile yapılan faaliyetlerde de hastanın kimlik bilgileri, rızası olmaksızın açılanamaz."

Görüldüğü üzere hastanın onamının olması durumunda dahi; kişilik haklarının tamamiyle ihlali sonucu oluşturabilecek bir durumda hastaya ait sırların açıklanması halinde açıklayan kişinin sorumluluğunun bulanacağı belirtilmiştir. Hasta kendi talepte bulunsa bile kişilik hakkının ihlal edilmesi sonucunu doğuracak bir bilgi açıklanamaz.

Kişisel sağlık verilerinin işlenmesi esnasında uygulanacak kurallar da hastaların özel hayatının gizliliği ve mahremiyet hakkının korunmasına ilişkin düzenlemeler içermektedir. Kişisel verilere ilişkin alanda önemli bir bölümünü ve özel nitelikli halini oluşturan kişisel sağlık verileri ile ilgili düzenlemeleri içeren "Kişisel Sağlık Verilerinin İşlenmesi ve Mahremiyetinin Sağlanması Hakkında Yönetmelik" 29863 sayılı ve 20 Ekim 2016 tarihli Resmi Gazete'de yayımlanarak yürürlüğe girmiştir. Yönetmeliğin 4. maddesine göre "Kimliği belirli veya belirlenebilir gerçek kişiye ilişkin her türlü sağllk bilgisi" kişisel sağlık verisi olarak kabul etmektedir. Yönetmeliğin m.5/1'de "Kişisel sağlık verilerinin, ancak Kanunda ve bu Yönetmelikte öngörülen usul ve esaslara uygun olarak işlenebilceği" düzenlenmiştir. 


\subsection{Sağlık Turistinin Özel Hayatının Gizliliği ve Mahremiyetinin Ko- runması Hakkı}

Sağlık turistlerinin farklı ülkelerde sağlık hizmetlerinden yararlanmayı istedikleri süreçte kişisel verilerine ilişkin pek çok bilgiyi kendi rızalarıyla ilgili birimlerdeki çalışanlarla paylaşmak durumunda kalmaktadırlar. Paylaşılan bu bilgilerin gizli tutulması yasanın ve hastaları rızasının dışında açıklanmaması sağlık turistinin özel yaşamının ve mahremiyetinin korunması açısından önem taşımaktadır (Sert, 2008, s.103). Sağlık turistinin özel hayatının korunması ve mahremiyetine ilişkin bazı durumlar sağlık turizminin doğasından kaynaklanan olgusal kökenli sorunlardır. Bunlardan ilki sağlık turistinin bir aracı kurum vasıtasıyla gelmesi durumunda sağlık turistinin kişisel verileri, sağlık turizmi sürecinin olağan akışı gereği öncelikli olarak aracı kurum ile paylaşılmakta ve bu kişisel veriler sağlık profesyoneli olmayan aracı kurum yetkilileri tarafından görüş (fiyat veya tıbbi görüş vb.) alınmak amacıyla çoğunlukla elektronik ortamda başka kişilerle paylaşılmaktadır. Her ne kadar Sağlık Turizmi Yönetmeliği'nin genel hükümlerinde aracı kurumların faaliyet alanı "sağlık turisti ve refakatçisinin konaklama, ulaşım ve transfer hizmetlerinin sağlanması" olarak belirlenmiş olsa da, Yönetmeliğin Ek- 2 m.6-c'de aracı kurumların taahhüt ettiği işler arasında "Uluslararası sağlık turistinin almak istediği sağllk hizmetine uygun olan sağllk tesislerini, sağllk turistinin tıbbi bilgi ve / veya belgelerini önceden sağllk tesisine ileterek araştırmak" olduğu görülmektedir. Görüldüğü üzere aracı kurumların faaliyet alanı tıbbi hizmetlerin dışında kalan işler olmayıp, sağlık turistlerine ilişkin özel nitelikli kişisel veriler bu kurumlar tarafından elde edilmektedir. Ancak özel nitelikli bu kişisel sağlık verilerinin aracı kurum yetkilileri tarafından saklanması, iletilmesi, güvenliğinin sağlanması ve bu bilgilere erişecek yetkili kişilerin belirlenmesine ilişkin bir düzenleme bulunmamaktadır. Serbest piyasanın koşullarıyla ve teknolojik imkanlar ölçüsünde bu bilgiler elde edilmekte, paylaşılmakta ve saklanmaktadır. Her ne kadar Sağlık Turizmi Yönetmeliğin EK.2 mad 6/i de aracı kurumlar tarafından sağlık turistine ait kişisel verilerin gizliliğine ilişkin "Faaliyetleri sırasında uluslararası să̆glk turistine ait elde ettiği her türlü bilgi hususunda, 24.3.2016 tarihli ve 6698 sayll Kişisel Verilerin Korunması Kanununa uygun bir şekilde hareket etmesi" 
şeklinde çerçeve kanuna gönderme yapılmış olsa da söz konusu aracı kurumların A sınıfı seyahat acentesi olduğu dikkate alınırsa, böylesi hassas sağlık verilerinin söz konusu aracı kurumlar tarafından yeterli dikkat ve özenle korunmalarını beklemek gerçekçi bir beklenti olmayabilir.

Sağlık turistlerinin kişisel verilerinin korunmasına ilişkin Yönetmelikteki bir başka düzenleme m.12/2-d'de aracı kurumların web sitelerinde "bilgilendirme ve tanitım" yapmaları durumunda "tanttmlarda; tedavi gören hastalarm hikâyelerine, hasta mahremiyeti gözetilmek, hasta haklarnna uygun olmak ve bu konuda hasta onaminin alındığını belgelendirmek kaydıyla yer verebilecekleri"ne ilişkin bir başka sorunlu düzenleme bulunmaktadır. Yönetmelikte, sağlık profesyoneli dahi olmayan bu acentaların özellikle hasta hakları gibi nitelikli bir bilgi düzeyinde olmaların beklemek bizce gerçekçi değildir. Hastadan ne şekilde onam alınacağına ilişkin sağlık prosfesyonellerinin bile yerleşmiş standarları henüz yokken böylesi bir yetkinin aracı kurumlara verilmesi tartışılması gereken bir husustur.

Sağlık turistinin mahremiyetine ilişkin bir diğer sorunlu alan ise daha komplekstir. 13/07/2017 tarih ve 30123 sayılı Resmi Gazete'de yayımlanan "Uluslararası Sağlık Turizmi ve Turistin Sağlığı Hakkında Yönetmelik" in 5. maddesinin 5. fikrasında "Uluslararası sağlık turizmi sağhlk tesisi tarafından, bu Yönetmelik kapsamında sağlık hizmeti verilen kişilerin Bakanlıkça oluşturulan web tabanl sisteme kaydedilmesi zorunludur." 6. fikrasında "Uluslararası sağlık turizmi sağlık tesisi tarafından kayıt altına alınan kişisel sağlık verileri, 24/3/2016 tarihli ve 6698 sayılı Kişisel Verilerin Korunması Kanununa uygun bir şekilde işlenir ve Bakanlıkça belirlenen usul ve esaslara uygun bir şekilde merkezi sağllk veri sistemine aktarllır." 7. fikrasında ise "Uluslararası sağllk turizmi sağllk tesisi ve uluslararası sağlık turizmi aracı kuruluşu, Bakanlıkça istenilen bilgi ve belgeleri göndermekle yükümlüdür." düzenlemesi ile başka bir tartışma yaratmıştır.

Bu düzenlemenin iptali için sağlık meslek örgütleri tarafından açılan davada Danıştay 15. Daire, 17.01.2018 tarihinde 2017/2258.E sayılı yürütmeyi durdurma talebini kabul etmiştir. Durdurma gerekçesi “ ...Bu durumda 6698 Sayılı Kişisel Verilerin Korunması Kanunu ile, sağhık verileri gibi özel nitelikli kişisel verilerin işlenmesinde uyulacak önlemlerin belirlenmesinde yetkili kılınan Kişisel Verileri Koruma Kurulu henüz oluşturulmadan ve adı geçen kurul tarafindan bu alana ilişkin yeterli önlemler ... işlem tesis edilmesini 
öngören dava konusu Yönetmeliğin 5. maddesi 6.fikrasinda hukuka uygunluk bulunmamaktadır." şeklindendir. Söz konusu kararda Kişisel Verileri Koruma Kurulu 6698 sayılı KKVK'nun 6. Bölümü 19-27. maddeleri arasında düzenlenmiştir. Kurulun görev ve yetkilerinin düzenlendiği m.22'de

a) Kişisel verilerin, temel hak ve özgürlüklere uygun şekilde işlenmesini sağlamak.

b) Kişisel verilerle ilgili haklarmm ihlal edildiğini ileri sürenlerin şikâyetlerini karara bağlamak.

c) Şikâyet üzerine veya ihlal iddiasın öğrenmesi durumunda resen görev alanna giren konularda kişisel verilerin kanunlara uygun olarak işlenip işlenmediğini incelemek ve gerektiğinde bu konuda geçici önlemler almak.

d) Özel nitelikli kişisel verilerin işlenmesi için aranan yeterli önlemleri belirlemek.

h) Diğer kurum ve kuruluşlarca hazırlanan ve kişisel verilere ilişkin hüküm içeren mevzuat taslakları hakkında görüş bildirmek." olarak belirlenmiştir. Görüldüğü üzere Danıştay, Yönetmeliğin yürütümünün durdurulmasında esasa ilişkin bir inceleme yapmadan yalnızca usulen gördüğü eksiklikten dolayı hukuka aykırı bulmuştur.

Yönetmeliğe göre sağlık turistinin özel nitelikli kişisel verileri olarak kişinin, uyruğu, pasaport numarası, başvurduğu klinik, geliş nedeni, teşhis ve tedaviye ilişkin kayıtlar sisteme girilmektedir. 6698 Sayılı Kanunun 6/1. madde hükmü ile kişinin sağllğına ilişkin verilerin özel nitelikli kişisel veriler olduğu kabul edilmiştir. 108 sayılı Avrupa Konseyi Sözleşmesinin 6. maddesi de, hassas kişisel verilere ilişkindir. Bu maddeye göre; "sağllk veya cinsel yaşama ilişkin kişisel verilerin, iç hukukta gerekli önlemlerin alınmış olması durumu dışında, otomatik olarak işlenemeyeceği" hüküm altına alınmıştır. Sağlık alanında kişisel verileri, kişinin sağlık hizmeti almak için bir sağlık kuruluşunda yapmış olduğu tüm işlemler olarak tanımlayabiliriz (Yılmaz, 2014, s. 45). Kişisel Verilerin İşlenmesi, KVKK'nın tanımlar alt başlıklı üçüncü maddesinin (e.) bendinde tanımlanmıştır. Buna göre, "Kişisel verilerin tamamen veya kısmen otomatik olan ya da herhangi bir veri kayıt sisteminin parçası olmak kaydıyla otomatik olmayan yollarla elde edilmesi, kaydedilmesi, depolanması, muhafaza edilmesi, 
değiştirilmesi, yeniden düzenlenmesi, açıklanması, aktarılması, devralınması, elde edilebilir hale getirilmesi, sinuflandırılması ya da kullanılmasinin engellenmesi gibi veriler üzerinde gerçekleştirilen her türlü işlem", kişisel verilerin işlenmesi olarak tanımlanmıştır. Bu tanım "Kişisel Sağlık Verilerinin İşlenmesi ve Mahremiyetinin Sağlanması Hakkında Yönetmelik m.4/1g'de de "kişisel sağlık verilerinin işlenmesi" tanımında aynen korunmuştur.

Kişisel Verilerin İşlenmesine dair genel ilkeler, KVKK Genel İlkeler başlıklı dördüncü maddede düzenlenmiştir. KVKK dördüncü maddesinin birinci fıkrasına göre; "Kişisel Veriler yalnız KVKK ve diğger kanunlarda öngörülen usul ve esaslara uygun olarak işlenebilir." Yine ayn maddenin ikinci fikrasında ise kişisel veriler işlenirken uyulması gerekli olan ilkeler belirtilmiştir. Bunlar; "hukuka ve dürüstlük kurallarına uygun olma, doğru ve gerektiğinde güncel olma, belirli, açık ve meşru amaçlar için işlenme, işlendikleri amaçla bağlantıll, sinırlı ve ölçülü olma ve ilgili mevzuatta öngörülen veya işlendikleri amaç için gerekli olan süre kadar muhafaza edilmedir." Kanunda belirtilen bu ilkeler "Kişisel Sağlık Verilerinin İşlenmesi ve Mahremiyetinin Sağlanması Hakkında Yönetmelik"m.5/2'de aynen tekrarlanmış ve bunlara ek olarak kişisel sağlık verileri m.5/3'te “(Değişik:RG24/11/2017-30250) Sağlık hizmeti sunumunda görevli kişiler, ilgili kişinin sağlık verilerini ancak verilecek olan sağlık hizmetinin gereği ile sınırl olmak kaydıyla işleyebilir." hükmü eklenmiştir.

Özel nitelikli kişisel verilerin işlenmesini düzenleyen ve KVKK'nın özel nitelikli kişisel verilerin işlenmesi şartları başlığını taşıyan altıncı maddesinin birinci fikrası özel nitelikli kişisel verileri tanımlamıştır. Kişinin sağlık, cinsel hayat ve biyometrik ve genetik bilgileri "özel nitelikli kişisel veri" olarak kabul edilmektedir. Maddenin ikinci fikrasında özel nitelikli kişisel verilerin ilgili kişinin açık rızasının olmadan işlenmesini yasaklamıştır. Aydınlatılmış onam da denilen açık rızanın bilgilendirmeye dayalı, kişinin özerk kararıyla verdiği ve yalnızca o işlemle sinırlı iznidir (Zeybek Ünsal vd, 2018, s. 84). Maddenin üçüncü fıkrası, ikinci fıkranın istisnası olup fikrada, "Birinci fikrada sayılan sağllk ve cinsel hayat dışındaki kişisel veriler, kanunlarda öngörülen hâllerde ilgili kişinin açık rızası aranmaksızın işlenebilir. Sağlık ve cinsel hayata ilişkin kişisel veriler ise ancak kamu sağhı̆̆ını korunması, koruyucu hekimlik, tıbbî teşhis, tedavi ve 
bakım hizmetlerinin yürütülmesi, sağlık hizmetleri ile finansmanının planlanması ve yönetimi amacıyla, sır saklama yükümlülü̈̆̈̈ altında bulunan kişiler veya yetkili kurum ve kuruluşlar tarafindan ilgilinin açık rızası aranmaksızın işlenebilir." denilmektedir. Ancak bu gibi durumlarda veriler, ulusal yasalara veya mesleki gizlilik yükümlülügüne dair yetkili ulusal kurumlar tarafından geliştirilen normlara göre, sağlık görevlileri veya aynı düzeyde gizlilik yükümlülügü bulunan diğer kişiler tarafından işlenebilecektir (Kaya, 2011, s.330). Maddenin son fıkrasında ise "Özel nitelikli kişisel verilerin işlenmesinde, ayrıca Kurul tarafindan belirlenen yeterli önlemlerin alınması şarttır" denilmiştir. Yeterli önlemlerin ne olduğu belirtilmemiştir. Bu noktada bilgi güvenliğinin üç sac ayağı olan kullanılabilirlik - gizlilik - bütünlük ilkelerine uygun bir biçimde alınabilecek teknik ve hukuki önlemler olabilir (İmamoğlu, 2017, s.15).

Kişisel sağlık verilerinin, Kanun ve Yönetmelikte belirtilen işlendikleri amaçla bağlantılı olarak, sınırlı ve de ölçülü olma ilkesi, işlenen verilerin, belirlenen amaçların gerçekleştirilebilmesine olanaklı olmasını, amacın gerçekleştirilmesiyle ilgili olmayan veya ihtiyaç duyulmayan kişisel verilerin işlenmesinden kaçınılmasını gerekli kılmaktadır (İmamoğlu, 2017, s.13). Dürüstlük kuralına uygunluk ilkesi gereğince, verinin kim/kimler tarafından, nasıl kullanılacağına ilişkin bilginin açık ve anlaşılır bir şekilde veri sahibine verilmesi gerekmektedir (Zeybek Ünsal vd, 2018, s. 84).

Sağlık kuruluşu hizmet verdiği sağlık turistine ilişkin olarak hangi verilerin, nasıl bir işlemden geçerek merkezi sisteme gönderileceğine ilişkin bir düzenleme belirtilmemiş ve sağlık kuruluşlarına kişisel sağlık verilerinin, Bakanlığa aktarım yükümlülüğü ile kişisel veri sahibine karşı olan sır saklama yükümlülükleri arasında ki hassas denge ihmal edilmiştir.

$\mathrm{Bu}$ noktada sağlık turistinin kişisel sağllk verilerinin işlenmesi ülkedeki sağlık hizmetleri planlamasının yapılması, bölgesel bazda ihtiyaçların belirlenmesi bağlamında yararlı olabilecek bir uygulamayken, sahibi belirlenebilir kişisel sağlık verilerinin kullanılması özel hayatın gizliliği ve mahremiyetin sınırlarının çizilmesi açısından tartışmalı bir husustur. 


\section{Sonuç ve Tartışma}

Uluslararası sağlık turizmi Türkiye' de devlet tarafından teşvik edilen bir sektördür. Çeşitli paydaşların yer aldığı bu sektörde sağlık turisti bu paydaşların her biriyle farklı hukuki ilişki kurmak zorundadır. Kurulan her ilişkide özel hayatın gizliliğini ve mahremiyetinin korunmasını yasal bir yükümlülüktür.

Sağlık turistinin sağlık kurumunun dışında ilk ilişki kurduğu kurum, Türk mevzuatına göre sağlık sektörüne tamamen yabancı olan aracı kurum olarak adlandırılan seyahat acentalardır. Yabancı hastanın kişisel sağlik verileri bu kişilerce hastane ve hekimlerden fiyat, tıbbi yönlendirme, görüş vb almak amacıyla çeşitli yollarla yayılmaktadır. Bu aracı kurumların sağlık turistlerine ait sağlık verilerini saklamaları, depolamaları, aktarmaları ve bilgilere kimlerin erişebileceğine ilişkin standartlar henüz oluşturulmadığından uygulamaya ciddi ihlaller yapılmaktadır. Diğer taraftan sağlık kurumlarında sağlık çalışanlarının da en fazla ihlal edilmesi mümkün haklardan biri hastanın özel hayatının gizliliği ve mahremiyet hakkıdır. Henüz hastanın bu hakkı konusunda sağlık çalışanlarına yönelik yeterince eğitim ve farkındalık sağlayamadan bu farkındalığı sağlık sektörü dışında ki aracı kurumlardan beklemek gerçekçi bir beklenti olmayacaktır. Bu noktada ki çözüm önerimiz sağlık turizmi yapma yetkisi verilen seyahat acentalarının mesul müdürünün mutlaka hekim veya sağlık yöneticisi olmasıdır.

Bir başka önemli husus, uluslararası sağlık turistine hizmet veren sağllk kuruluşu, Sağlık Turizmi Yönetmeliği gereği hastaya ait tüm özel nitelikli sağlık bilgilerini Sağlık Bakanlığına aktarmakla yükümlüdür. Sağlık turistine ilişkin tüm verilerin anonimleştirilmeden, güvenliği sağlanmadan, bu verilerin nasıl bir işleme tabi tutulacağı belirtilmeden Bakanlığa aktarılması Türkiye'nin taraf olduğu uluslararası sözleşmelere ve ulusal mevzuata aykırıdır.Yabancı hastalara ilişkin kişisel veriler ancak anonimleştirilerek ve amacına uygun bir şekilde merkezi sisteme aktarılması uluslararası sağlık turisrtinin özel hayatının gizliliğini koruma adına bir gerekliliktir. 
EXTENDED ABSTRACT

\title{
The Right to Protect Privacy and Private of Life of the Patient in International Health Tourism
}

\author{
Ayşegül Karaca Dedeoğlu \\ Karabük University
}

International health tourism means receiving individuals health care needs from a foreign country. The main reasons of international health tourism is the demand for more quality, economic and accessible health services. Also, the importance given to the privacy and secrecy of patient's private life can be added. In this process health tourist has expectations and requests from each individual, institution and the state of the country that he or she contacted, for disguise his or her information related to private life and protection of this information from others.

In the relationship between patient and doctor, protecting the privacy of the patient is very important. Privacy is not only about to not reveal relationship between the person with whom he or she has a very close relationship; at the same time to make their own choices, to be able to freely create their thoughts and behaviours and to be able to arrange their own information and relations with others. The concept of "private life" can be defined as "subjects of a person that provided with private research and knowledge, which only for himself and wants others to stay away from this information". As a result of doctor's respect to privacy of patient's private life, the patient will be able to share his sensitive personal information more comfortably with doctor. The protection of this patients right is largely dependent on private or public legal entities other than the patient. Because the patient has to share a lot of information about himself before, during and after the treatment process. These data what we call personal health data; is any kind of health information about real person that is specific or identifiable.

The concept of privacy of patient doesn't just involve information about the patient's disease. It is also necessary to understand the personal, 
family, professional, economic and financial situation of the patient. There are regulations on patient privacy in international declarations such as the Hippocratic Oath, the 1981 Lisbon Declaration on Patient Rights, the Amsterdam Declaration in 1994 and the Bali Declaration in 1995. Article 12 of the Universal Declaration of Human Rights concerns the right to respect for private life. Article 17 of The International Covenant on Civil and Political Rights contains provisions on the privacy of private life. Article 16 of The Convention on the Rights of the Child in 1991, Article 11/2 of the American Convention on Human Rights and Article 29 of African Charter on Human and Peoples' Rights regulates the protection of private life. Article 8 of European Convention on Human Rights states that everyone has the right to respect for private and family life. Article 10's title of Convention for the Protection of Human Rights and Dignity of the Human Being with regard to the Application of Biology and Medicine: Convention on Human Rights and Biomedicine is private life and right to be informed. The European Charter of Patient Rights provides additional new rights to patient rights in the previous international instruments before 2003. Article 20, 21and 22 of the 1982 Constitution contain provisions for the protection of privacy. The Law on the Protection of Personal Data Number 6698 was published in 2016 and entered into force. Within the framework of the protection of private life, the Turkish Civil Code (Article 23) and the Turkish Code of Obligations (Article 49) also contain various provisions. Regarding the protection of personal data, the Turkish Penal Code Number 5237 has regulations (Article 135,136,137,138 etc.). In addition, there are many regulations in the Turkish health legislation that protect the rights of patients. In addition to the regulation in various special laws, the Regulation on Patient Rights of 1994 and "the Regulation on the Processing and Privacy of Personal Health Data" that came into force in 2016, aims to protect the rights and privacy of the patients and their personal data.

Health tourism is a big industry because it has multiple stakeholders. There are not only health facilities in the health tourism industry. There are also sub-sectors such as medical tourism facilitator companies, accommodation centers, transportation, communication and marketing. Due to the structure of health tourism, it is affected by all changes and legal regulations in these sectors. Health tourists make contract or hospital admission agreement with health service provider. Similarly, for example; the 
transport contract with airline company for transportation; hosting agreement with hotel for accommodation. On the other hand patient may choose an medical tourism facilitator companies to mediate the establishment of all these relations. Health tourists share their personal data with intermediary institutions in order to benefit from health services from different countries. In order to protect the private life of the health tourist, it is important that this shared information is kept secret and that it is not disclosed outside the law and the consent of the patient.

According to Turkish legislation, the institution where the health tourist first establishes a relationship with the health institution is the travel agency. The personal health data of the foreign patient can spread in various ways by these people to get prices, etc. from hospitals and physicians. Violations can occur in practice, as the legal standards for hiding, transmitting and accessing health data of health tourists by these agencies have not yet been established.

Article 5/5-6-7 of the Regulation on Health Tourism, which entered into force in 2017, is based on the transfer of all personal data related to health services and health tourists to the central health data system. According to the regulations, as the personal data of the health tourist, the records of the person, his nationality, his passport number, the clinic, the reason for the arrival, diagnosis and treatment are entered into the system. With the Article 6/1 on the Law number 6698, data on the health of the person is deemed to be private personal data. Article 6 of the Council of Europe Convention No. 108 also based on sensitive personal data. According to this article; "Personal data relating to health or sexual life cannot be processed automatically unless the necessary measures are taken in domestic law". In the healthcare field, we may define personal data as all transactions that a person has made in a health care facility to receive health care. The Processing of Personal Data is defined in subparagraph (e.) of the third article under the definitions subtitle of the KVKK. According to this "Any transaction on personal data such as obtaining or recording, storing, changing, rearranging, disclosing, transferring, taking over, making available, making, classification, the prevention of use" is defined as the processing of personal data. This definition also preserved in article 4/1 of personal health data processing definition on "Regulation on the Pro- 
cessing of Personal Health Data and Privacy Protection". The general principles for the processing of Personal Data are set out in the fourth article entitled "General Principles of KVKK". According to the first paragraph of the fourth article of the KVKK; "Personal Data may be processed only in accordance with the procedures and principles set forth in the KVKK and other laws". In the second paragraph of the same article, the principles which must be followed while the personal data are processed are indicated. These are "to comply with the rules of law and integrity, to be accurate and being up-to-date when necessary, processing for specific, clear and legitimate purposes, to be connected, limited and measured with the purpose of processing or should be kept for the purpose for which they are processed."

The first paragraph of the sixth article, which regulates the processing of special personal data and which is entitled to the processing of personal data of the KVKK, has defined the special personal data. Personal health, sexual life and biometric and genetic information of the person has been considered as private qualified personal data. In the second paragraph of the article, it prohibits the processing of special personal data without the express consent of the concerned person. The informed consent which is also called clear consent, shall be given only by the autonomous decision of the person, informative and limited to that operation. The principle of personal health data linked, limited and measured to the purpose as specified in the Law and Regulation, requires that the processed data is suitable for the achievement of the set objectives and avoiding the processing of personal data that is not related to the realization of the objective.

In the first part of this study, international health tourism and its causes and stakeholders were examined. In the second chapter, the basic concepts such as privacy, private life's privacy, personal data are discussed in the light of international declarations and conventions and national legislation. Document analysis method, which is one of the qualitative research methods, was used as a method in the study.

\section{Kaynakça / References}

Afrika İnsan ve Halkların Hakları Şartı, https://burakgemalmaz.files.wordpress.com/2015/05/01-1981-june-27-af-ihhc59f.pdf Erişim. 07.09.2018. 
Amerikan İnsan Hakları Sözleşmesi , https://burakgemalmaz.files.wordpress.com/2015/05/02.pdf Erişim 14.08.2018.

Araslı, O. (1979). Özel yaşamın gizliliği hakkı ve T.C. Anayasasında düzenlenişi. Yayınlanmamış Doçentlik Tezi, Ankara.

Aslanova, K. (2013). Türkiye'de sağlık turizmi ve sağllk turizmi hukuku. Avrasya Uluslararası Araştırmalar Dergisi, 2(3), 129-145.

Avrupa Hasta Hakları Şartı, http://www.journalagent.com/z4/vi.asp?pdir=tjob\&plng=tur\&un=TJOB-69775 Erişim 12.09.2018.

Avrupa Hasta Haklarının Geliştirilmesi Bildirgesi-Amsterdam Bildirgesi http://istanbul.mazlumder.org/tr/main/yayinlar/sozlesmeler/18/avrupa-hasta-haklarinin-gelistirilmesi-bildir/440 Erişim 13.09.2018.

Avrupa İnsan Hakları Sözleşmesi, https://www.echr.coe.int/Documents/Convention_TUR.pdf Eriişim 11.09.2018.

Aydın, G. ve Karamehmet Aydın, B. (2015). Dünya'da ve Türkiye'de sağlık turizmi pazarlama uygulamaları ve karşılaştırmalı durum analizi. Pazarlama ve Pazarlama Araştırmaları Dergisi, (16), 1-21.

Aydın, SE. (2014). AİHM içtihatları bağlamında kişisel verilerin kaydedilmesi suçu. Yayınlanmamış Yüksek Lisans Tezi., İstanbul Üniversitesi, Sosyal Bilimler Enstitüsü, İstanbul.

Bali Bildirgesi http://www.hayad.org.tr/bali-bildirgesi-1995 Erişim 02.09.2018.

Birdir, K. ve Buzcu, Z. (2014). JCI akreditasyon belgesine sahip olan sağlık kuruluşlarının web sitelerinin medikal turizm açısından değerlendirilmesi. Çă̆ Üniversitesi Sosyal Bilimler Dergisi, 11(1), 1-20.

Birleşmiş Milletler Çocuk Haklarına Dair Sözleşme https://www.unicef.org/turkey/crc/_cr23c.html Erişim. 06.08.2018.

Biyotıp Sözleşmesi https://www.echr.coe.int/Documents/Convention_TUR.pdf Erişim, 30.09.2018.

Borazan, M. (2015). Gizlilik, bireysel haklar ve kişisel verilerin korunması. Inet-Tr'15, XX. Türkiye'de İnternet Konferansı, İstanbul Üniversitesi, 203-207.

Cate, FH.(2003) .The Privacy Problem. A First Amendment Center Publication. 
Cohen, I. G. (2010). Protecting patients with passports: medical tourism and the patient-protective argument. Iowa Law Review, 95, 14671567.

Conley, J. (2013). Medicare and medical tourism: saving medicar with a global approach to coverage, Elder The Elder Law Journal, 21, 183222.

Çaykent, Ö. (2014). Mahrem üzerinden devletin özelini tanımlamak: Kamusal ve özel alan karmaşası. Evrensel Kültür, 269, 1-7.

Dinç, G.( 1987). Bilgisayar çağında özel hayatın korunması. Ankara Barosu Dergisi.2.

Dülger, MV. (2016). Kişisel verilerin korunması kanunu ve Türk ceza kanunu bağlamında kişisel verilerin ceza normlarıyla korunması. İstanbul Medipol Üniversitesi Hukuk Fakültesi Dergisi, 3 (2), 101-167.

Dülger, MV.(2015). Sağlık hukukunda kişisel verilerin korunması ve hasta mahremiyeti. İstanbul Medipol Üniversitesi Hukuk Fakültesi Dergisi 1 (2), 43-80.

Elmalıca, H. (2016). Bilişim çağının ortaya çıkardığı temel bir insan hakkı olarak unutulma hakk1. Ankara Üni. Hukuk Fak. Dergisi, 65(4), 16031636.

Gavisont, R. (1980). Privacy and the limits of law. The Yale Law Journal, 89(3), 421-471.

Gönenç, Fİ.(2016). Hukuki ve etik boyutuyla medikal turizm. Prof. Dr. Cevdet Yavuz'a Armağan, Cilt I. Marmara Üniversitesi Hukuk Fakültesi Hukuk Araştırmaları Dergisi, 22(3), 1173-1184.

Hakeri, H. (2013). Tıp hukuku. Ankara: Seçkin Yayıncılık, 7.Baskı.

http://saglikturizmi.gov.tr/TR,175/saglik-turizmi-hakkinda.html Erişim 30.10.2018.

http://www.oecd.org/internet/ieconomy/oecdguidelinesontheprotectionofprivacyandtransborderflowsofpersonaldata.htm\#part1 Erişim 04.12.2018.

http://www.ttb.org.tr/haber_goster.php?Guid=54b82ace-2220-11e8-82e95e6c03ccf873 Erişim 29.10.2018.

İmamoğlu, DA. (2017). 6698 Sayılı kişisel verilerin korunması kanunu uyarınca özel nitelikli kişisel verilerin işlenme şartları. https://bilgi.academia.edu/DenizAlp\%C4\%B0mamo\%C4\%9Flu Erişim 30.11.2018. 
İmre, Z. (1974). Şahsiyet haklarından şahsın özel hayatının ve gizliliklerinin korunmasına ilişkin meseleler. İstanbul Üniversitesi Hukuk Fakültesi Mecmuası, 39(1-4), 146-168.

İnsan Hakları Evrensel Beyannamesi http://www.unicankara.org.tr/doc_pdf/h_rigths_turkce.pdf Erişim 08.09.2018.

İzgi, M. C. (2014). Mahremiyet kavramı bağlamında kişisel sağlık verileri. Türkiye Biyoetik Dergisi, 1(1), 25-37.

Jones, B. M. (2010.) Libraries, technology, and the culture of privacy a global perspective. Privacy and Freedom of Information in $21^{\text {st }}$ Century Libraries, Library Technology Reports, 46(8), 94-107.

Kaboğlu, İ. (2002). Özgürlükler hukuku. İstanbul: İmge Kitabevi, 6. Baskı.

Katoğlu, T. (2006).Türk hukukunun bir parçası olarak Avrupa konseyi insan hakları ve biyotıp sözleşmesi. AÜHFD, 55(1), 157-193.

Kaya, C. (2011). Avrupa birliği veri koruma direktifi ekseninde hassas (kişisel) veriler ve işlenmesi. Ï̈̈HFM, LXIX(1 -2), 317-334,

Keser Berber, L. ve Ülgü, MM. ve Er, C.(2009). Elektronik sağllk kayıtları ve özel hayatın gizliliği. İstanbul Bilgi Üniversitesi, Bilişim Teknolojisi Hukuku, Uygulama ve Araştırma Merkezi.

Korkmaz, A. (2014). İnsan hakları bağlamında özel hayatın gizliliği ve korunması. Karamanoğlu Mehmetbey Üniversitesi Sosyal ve Ekonomik Araştırmalar Dergisi, I, 99-103.

Kutlu, Ö ve Kahraman, S.( 2017). Türkiye'de kişisel verilerin korunması politikasının analizi. Research Journal of Politics, Economics and Management, 5(4), 45-62.

Küzeci, E. (2018). Sağlık bilişim teknolojileri ve yeni hukuksal soru(n)lar. İnönü Üniversitesi Hukuk Fakültesi Dergisi-İNÜHFD- 9(1), 477-506.

Lizbon Hasta Hakları Bildirgesi http://www.hayad.org.tr/lizbon-hastahaklari-bildirgesi Erişim 23.09.2018.

Medeni ve Siyasi Haklara İlişkin Uluslararası Sözleşme https://humanrightscenter.bilgi.edu.tr/tr/content/117-medeni-ve-siyasi-haklarailiskin-uluslararas-sozlesme/ Erişim 24.09.2018.

OECD Guidelines on the Protection of Privacy and Transborder Flows of Personal Data.

Özsunay, E.(1982). Gerçek kişilerin hukuki durumu. İstanbul: İstanbul Üniversitesi Yayınları 
Rubenson, B. (2002). Health and Human Rights. Swedish International Development Cooperation Agency Department for Democracy and Social Development Health Division Health Division Document, 1-32.

Sağlık Turizminde Aracı Kurumlar, http://www.saturk.gov.tr/images/pdf/tyst/08.pdf Erişim 15.10.2018.

Salihpaşaoğlu, Y.( 2013). Özel hayatın kapsamı: Avrupa insan hakları mahkemesi içtihatları 1şığında bir değerlendirme. Gazi Üniversitesi Hukuk Fakültesi Dergisi, XVII(3), 227-266.

Sarp, N. (2011). Hekimlerin sır saklama yükümlülü̈̆̈̈̈, II. Sağllk Hukuku Sempozyumu, Ankara: Adalet Yayınevi.

Sayek, F. (2009). Sağlıkla ilgili uluslararası belgeler. Dünya Tabipler Birliği'nin Sağlık Veri Tabanları ile İlgili Etik Düşünceler Bildirgesi, İstanbul: TTB Yayınları.

Sert, G. (2004). Hasta hakları. (1. Basım), İstanbul: Babil Yayınları.

Sert, G. (2008). Tıp etiği ve mahremiyet hakkı. (1. Basım), İstanbul: Babil Yayinları.

Şen, E.(1996). Devlet ve kitle iletişim araçları karşısında özel hayatın gizliliği ve korunması. Kazancı Kitap Ticaret A:ş. İstanbul

Teke, A.; Uçar, M.; Demir, C.; Çelen, Ö. ve Karaalp, T. (2007). Bir eğitim hastanesinde görev yapan hemşirelerin hasta hakları konusundaki bilgi ve tutumlarının değerlendirilmesi, TSK Koruyucu Hekimlik Bülteni, 6(4), 259-266.

Türk Dil Kurumu http://www.tdk.gov.tr/index.php?option=com_gts\&arama=gts\&guid=TDK.GTS.5c07b23ab324f4.62309 3 Erişim, 05.10.2018.

Türk Dil Kurumu, Büyük Türkçe Sözlük, http://www.tdk.gov.tr/index.php?option=com_bts\&view=bts Erişim, 12.10.2018.

Uyanık, A. (2015). Sağlık turizmi hukuku. http://www.sdplatform.com/Dergi/904/ Saglik-turizmi-hukuku.aspx Erişim 24.05.2018.

Uyanık, A. (2015). Sinırötesi tele-tıp uygulamalarından kaynaklanan hukuksal sorunlar. I. Ulusal Sağlık Hukuku Kongresi. Ankara: Seçkin Yayınc1lik.

Üzeltürk, S.(2004). 1982 Anayasası ve insan hakları Avrupa sözleşmesine göre özel hayatın gizliliği Hakkı. İstanbul: Beta Yayın. 
Veatch, R. W.(2010). Biyoetiğin temelleri. (T. Güven, Çev.), (2. Basım). İstanbul: AND Danışmanlık ve Yayıncılık.

Warren, S. D. and. Brandeis, L.D. (1890). The right to privacy. Harvard Law Review, 4(5), 193-220.

Yılmaz, S. (2014). Tıp alanında kişisel verilerin açıklanması suçu. Ankara: Seçkin Yayıncilık.

Yüksel, M. (2003). Mahremiyet hakkı ve sosyo-tarihsel gelişimi. Ankara Üniversitesi Siyasal Bilgiler Fakültesi Dergisi, 1(58), 181-213.

Yüksel, M. (2009). Mahremiyet hakkına ve bireysel özgürlüklere felsefi yaklaşımlar, Ankara Üniversitesi SBF Dergisi, 64(1), 275-298.

Zeybek Ünsal, Ç. ve Örnek Büken, N. (2018). Biyotıp araştırmaları ile ilgili olarak, "kişisel verilerin korunması kanunu" ve "kişisel sağlık verilerinin işlenmesi ve mahremiyetinin sağlanması hakkında yönetmelik" ne diyor? Türkiye Klinikleri J Med Ethics Law Hist-Special Topics $4(1), 82-90$

\section{Kaynakça Bilgisi / Citation Information}

Karaca-Dedeoğlu, A. (2019). Uluslararası sağlık turizminde hastanın özel hayatının gizliliği ve mahremiyetinin korunması hakkı. OPUSUluslararası Toplum Araştırmaları Dergisi, 10(17), 1875-1910. DOI: 10.26466/opus. 480676 